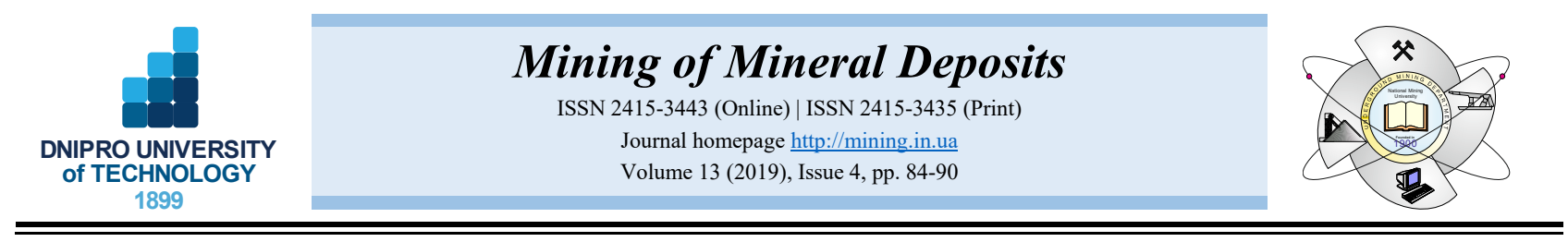

UDC 622.765.061

https://doi.org/10.33271/mining13.04.084

\title{
BENEFICIATION OF PHOSPHATE SLUDGE REJECTED FROM DJEBEL ONK PLANT (ALGERIA)
}

\author{
D. Nettour ${ }^{1 *}$, M. Chettibi ${ }^{2}$, G. Bulut ${ }^{3}$, A. Benselhoub ${ }^{2}$ \\ ${ }^{1}$ National School of Mines and Metallurgy (ENSMM), Annaba, Algeria \\ ${ }^{2}$ Badji Mokhtar University, Annaba, Algeria \\ ${ }^{3}$ Istanbul Technical University, Istanbul, Turkey \\ *Corresponding author: e-maildjamel.nettour@ensmm-annaba.dz,tel. +213655212300
}

\begin{abstract}
Purpose Flotation tests have been used in order to achieve the purposes of this study which are: To obtain the highest recovery with a maximum grade of $\mathrm{P}_{2} \mathrm{O}_{5}$ from the tailing generated by the phosphate plant of Djebel Onk in the East of Algeria. To get a good concentrate from the rejections, which gives an added value to the national economy. To preserve the human life and finally to protect the environment from the heavy metals contained in the tailings.

Methods. To reach our goals we have used: the granular and XRD analysis to characterize the tailing composition so as to choose the right reagents and conduct a good flotation. Flotation tests were carried out using Sodium Oleate as a collector and alkyl hydroxamic acid (AERO 6493) as collector and frother, zeta-meter system to measure the Zeta potential of the phosphate tailing and define the convenient values insuring the particles surfaces' best adsorption.

Findings. The granular analysis has allowed us to observe a main mode represented by the fraction less than $125 \mu \mathrm{m}$ equal to $76.77 \%$; the weight yield of the second mode of fraction $(-200+125) \mu \mathrm{m}$ is about $18 \%$; the third mode represents the coarse particle size range of a mesh of greater than $200 \mu \mathrm{m}$ represents only $4.94 \%$ in yield. However, in the case of AERO 6493, the recovery reaches $97 \%$ in condition $150 \mathrm{mg} / 1$ of concentrate and $26.51 \%$ grade of $\mathrm{P}_{2} \mathrm{O}_{5}$. On the other hand, the flotation test with the sodium oleate shows a low recovery with good content on $\mathrm{P}_{2} \mathrm{O}_{5}$ which reaches $30 \%$.

Originality. Since the beginning of phosphate production in Djebel Onk phosphate complex in 1965, tailings have been evacuated into the nature without any further treatment. The originality of this work lays in the recovery of phosphate in the fine slice on the one hand and the elimination of heavy metals drained in the tailing on the other hand.

Practical implications. Using the alkyl hydroxamic acid with different concentrations determined in the flotation tests leads to a greatest recovery of phosphate with minimum financial charges of exploitation, transport, crushing and grinding. In result, the productivity of the Djebel Onk complex can be increased and the environment can be preserved too.
\end{abstract}

Keywords: Djebel Onk phosphate complex, tailings, beneficiation, flotation, reagents, alkyl hydroxamic acid

\section{INTRODUCTION}

The industry generates great quantities of tailings throughout the world, particularly the mining industry, which produces a variety of rejections because of the intensification of mining activities and the increased need for raw materials. These residues must be managed in a rational and safe manner, even if neutralized, in order to protect the environment, preserve nature and human health. On the other hand, the mining industry has been the basis of the industrial sectors development for centuries. Mining activities have expanded and developed an amount of tailings, the deposition and storage of these later became a serious problem for the mining industry and environment threat, particularly over the last 30 years (Boujlel et al., 2018).

In modern mining industry, it is necessary to design and construct retaining dikes and slag heaps to store these tailings (Habashi, 2017).

There are legal international standards using for residues managing. In Europe, a draft legislation governing the management of residues was first published by the European Commission in October 2000. Today, the purpose of regulation No. 596/2009/EC published in 2009 in

(C) 2019. D. Nettour, M. Chettibi, G. Bulut, A. Benselhoub. Published by the Dnipro University of Technology on behalf of Mining of Mineral Deposits. This is an Open Access article distributed under the terms of the Creative Commons Attribution License (http://creativecommons.org/licenses/by/4.0/), which permits unrestricted reuse, distribution, and reproduction in any medium, provided the original work is properly cited. 
accordance with the European Union Directive 2006/21/EC on the management of mining residues is to stabilize for a long term the processing organs and reduce the negative effects of mining activities on the environment, such as leakage of acid, alkaline drainage and heavy metals (Yassine, 2017).

The requirement of certain standards and obligations contributes to the protection of natural resources, particular by promoting their recycling in order to improve the management of tailings and taking into account the risks for the environment and human health.

The mining industry residue management techniques depend on the type of tailings, the purpose of the method used, the regulation and the type of construction. Containment dams, dry disposal, in-situ disposal in the open pit, disposal in riverbeds, lakes and rivers, removal of residues in surface pastes and residue removal are the main methods used to treat rejections. Although tailings dams are the most widely used methods for mine waste disposal, they also cause many problems such as cost, environment and human health. There are approximately 3500 tailings dams in the world and 138 major dam's accidents have been reported in total in the last 15 years (Gallala et al, 2016).

The Algerian underground contains a high potential of raw materials phosphate, the proven reserves at the Jebel Onk deposit are currently estimated about 2 billion tons (Bezzi, 2005). The Jebel Onk phosphate mining complex was started in 1965, the residues of the latter being of the order of 5000 per day, these phosphate residues are discharged directly into the wild without any further treatment, with the presence of various heavy metals such as Uranium, Cadmium, Zinc, Copper and Arsenic, this is why, they are considered as harmful for the environment (Nettour, 2018). According to the literature on phosphate beneficiation, flotation is the most commonly method used for phosphate beneficiation with more than $80 \%$ of global production enriched by flotation (Nettour, Chettibi, Bouhedja, \& Bulut, 2018). The revalorisation and the sustainable management of the mining tailings appear as adequate settlements for the problems and the preoccupations of the mining industry (Rao, Velan, Jamal, \& Mahadevan, 2014).

So, the present work aims to find the beneficiation's possibility of phosphate tailings rejected by the phosphate complex of Jebel Onk in Eastern of Algeria. This study represents a great economic interest on the one hand, and on the other hand, human life protection and the environment preservation. Moreover, in this work an optimization of the physico-chemical properties of the phosphate tailing is made.

\section{MATERIALS AND METHODS}

Approximately $50 \mathrm{~kg}$ of the representative samples of phosphate tailings were taken from different points of the tailings locations. The chemical reagents used in the flotation tests are the sodium oleate which plays the role of the collector; alkyl hydroxamic acid is used as frother and collector agent to create hard and tenacious foam. Hydrochloric acid and sodium hydroxide were used to adjust the $\mathrm{pH}$ of the flotation pulp.
First the tailing were completely homogenized and then divided several times by the quartering mixingseparation method to obtain a manipulating sample, its weight is about $5 \mathrm{~kg}$. The sample was milled by a ceramic mortar mill to ensure that the particles sizes are less than $150 \mu \mathrm{m}$.

\subsection{Granular analysis}

In order to attain our goal, the sieving method eventually was used, which is one of several methods of granular analysis. This analysis is carried out to describe the granular composition of the product; as well as to determine the respective percentages and weight of the different fractions constituting the sample. These fractions consist of particles whose size cover a relatively small range to biggest one higher. In other words, this technique makes it possible to recover the separated fractions depending on the particles size (Horta, Monte, \& Leal-Filho, 2017)

An assortment of sieves consisting of: 500, 200, 180, 125,63 , and $45 \mu \mathrm{m}$ were used for sieving. The latter were mounted on a mechanical shaker for 10 minutes to get a complete separation of the particles according to their size.

\subsection{X-ray diffraction analysis (XRD)}

$\mathrm{X}$-ray diffraction analysis (XRD) was performed on samples of the tailing from the flotation feed, and the two products issued from the flotation in order to identify the mineralogical phases of the Jebel Onk complex tailing.

$\mathrm{X}$-ray diffraction analysis was carried out on a diffractometer $\theta / 20$ Rigaku Ultima IV, using $K_{\alpha}$ copper radiation $(\lambda=0.154056 \mathrm{~nm})$. The XRD images are recorded in the range from $5-90^{\circ}$ (in $2 \theta$ ) with a pitch $0.02^{\circ}$.

\subsection{Scanning electron microscope (SEM) analysis}

The microscopic observations on the flotation feed were carried out by scanning electron microscope (SEM), consisting of their imaging using a FTI QUANTA 250 microscope to study the morphology of the minerals which constitute the phosphate rejections.

\subsection{Zeta potential measurements}

Zeta potential measurements were made on pure mineral samples after mixing with different flotation reagents (sodium oleate and alkyl hydroxamic acid) at various concentrations. The instrument used in measuring was a zeta-meter; Malvern Instruments (Fig. 1).

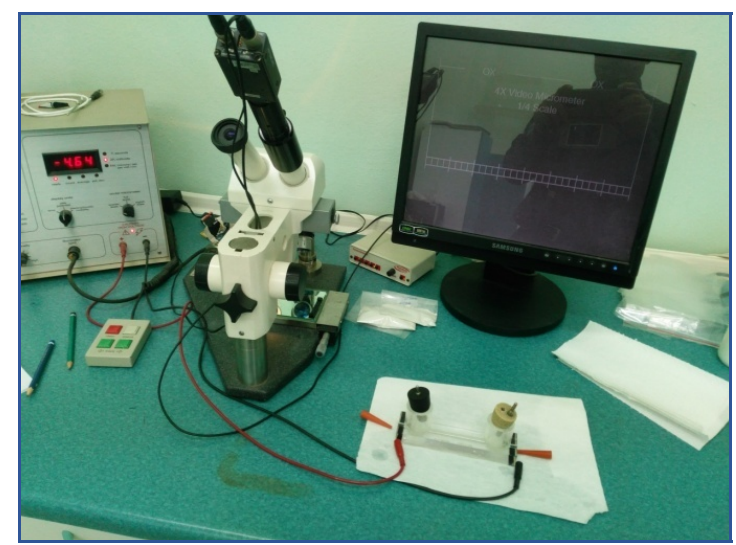

Figure 1. Zeta-meter system measurements 
All measurements were obtained at room temperature. The samples were prepared at $0.1 \%$ by weight of mineral in a solution at different concentrations. The prepared mineral suspension was stirred with an electrical stirrer for 5 minutes. The $\mathrm{pH}$ of the solution was adjusted using $1 \mathrm{Mol}$ of either $\mathrm{HCl}$ or $\mathrm{NaOH}$ as needed.

\subsection{Flotation tests}

Mostly, flotation in conventional equipment gives good results for particles that are typically in the particle size range of 20 to $150 \mu \mathrm{m}$ in diameter for base metal ores such as: chalcopyrite, malachite, galena, sphalerite and others). But for the phosphate ores: (apatite, fluorapatite, francolite, vivianite etc.) the flotation works very well for particles with size fraction from 38 to 200 microns (Chettibi, 2014).

The representative samples, after being homogenized, were collected and sieved. The recommended optimum size for the flotation in the case of phosphate minerals is between 38 and $150 \mathrm{~m}$ (Chettibi, Boutrid, Laraba, \& Abramov, 2015; Chettibi \& Abramov, 2016). Thus, the size of the flotation charge used in this study was the fraction $-100+38 \mu \mathrm{m}$, obtained by sieving. The flotation tests were carried out using a Denver D-12 flotation cell, the capacity of its tank is 1 liter; the rotor speed was set at $1200 \mathrm{rpm}$ in all flotation experiments. The pulp was conditioned for 5 minutes with all the reagents at standard $\mathrm{pH}$ conditions, pure water was used in all tests. The reagents used are the alkyl hydroxamic acid collector and frother (AERO 6493) and sodium oleate $\left(\mathrm{C} 18 \mathrm{H} 33 \mathrm{NaO}_{2}\right)$ as a collector, the $\mathrm{pH}$ regulators used are hydrochloric acid $(\mathrm{HCl})$ and sodium hydroxide $(\mathrm{NaOH})$. The recovery of phosphate minerals was calculated from the dry weight of the two flotation products: concentrates and tailing using Equation (1):

Recovery $(\%)=\frac{C \beta}{Q \alpha} \cdot 100$,

where:

$Q$ - feed weight in g;

$C$ - concentrate weight in $\mathrm{g}$;

$\alpha$ - phosphate content in feed $\%$;

$\beta$-phosphate content in concentrate, $\%$.

\section{RESULTS AND DISCUSSION}

\subsection{Tailings characterization}

The granular analysis of the phosphate tailing rejected from the Djebel Onk plant makes it possible to determine the weight distribution of the grains constituting the studying sample. The variation of the weight yield as a function of the granular fractions obtained by sieving is characterized by 03 modes. The main mode M1 represented by the size less than $125 \mu \mathrm{m}$ equals $76.77 \%$ by weight; the weight yield of the second mode M2 limited in the fraction of $(-200+125) \mu \mathrm{m}$ is about $18 \%$ weight, and the third mode M3 represents the coarse particle size range higher than $200 \mu \mathrm{m}$ represents only a yield of 4.94\% (Fig. 2).

The variation of the weight yield as a function of the granular fractions obtained by sieving is characterized by 03 modes.

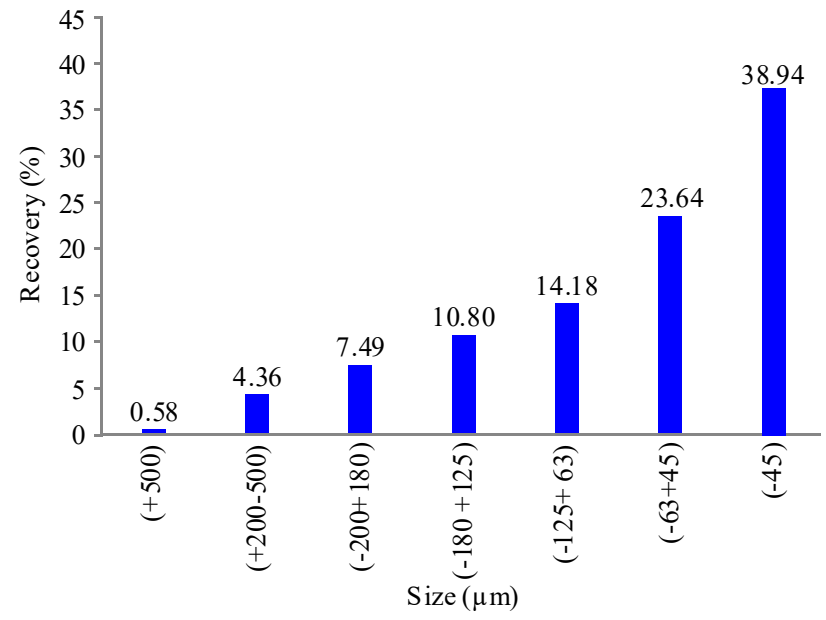

Figure 2. Size distribution of studying sample

The main mode $\mathrm{M} 1$ represented by the size less than $125 \mu \mathrm{m}$ equals $76.77 \%$ by weight; the weight yield of the second mode M2 limited in the fraction of $(-200+125) \mu \mathrm{m}$ is about $18 \%$ weight, and the third mode M3 represents the coarse particle size range higher than $200 \mu \mathrm{m}$ represents only a yield of $4.94 \%$ (Fig. 2).

$\mathrm{XRD}$ is one of the non-destructive techniques of multi-component mixtures; it allows a commonly utilities, first a rapid analysis to identify the different mineral species included within a material as well as their size parameters. And second it can also be used to access quantitative information such as the relative proportion of each species in a matrix and can justify the nature and sometimes quantify the crystalline minerals constituting the solid phases too (Ibrahim, El Kammar, \& Guda, 2015). For the recording of the diffractograms, it is ne-cessary to prepare special pasts from the sample preliminary grinded till a particle size close to 30 microns.

The obtained results of XRD tests highlight the presence of phosphate elements of the apatite class such as: Carbonate apatite $\left[\mathrm{Ca}_{10}\left(\mathrm{PO}_{4}\right)_{6}\right]$, Carbonate hydroxyapatite $\left[\mathrm{Ca}_{10}\left(\mathrm{PO}_{4}\right)_{3}\left(\mathrm{CO}_{3}\right)_{3}(\mathrm{OH})_{2}\right]$, Fluorapatite $\left[\mathrm{Ca}_{5}\left(\mathrm{PO}_{4}\right)_{3} \mathrm{~F}\right]$, Carbonate fluorapatite $\left[\mathrm{Ca}_{10}\left(\mathrm{PO}_{4}\right)_{5} \mathrm{CO}_{3} \mathrm{~F}_{1,5}(\mathrm{OH})_{0,5}\right]$ the hydroxyapatite $\left[\mathrm{Ca}_{5}\left(\mathrm{PO}_{4}\right)_{3}(\mathrm{OH})\right]$ and hydrated phosphate, but the gangue elements are represented essentially by: the dolomite $\left[\mathrm{CaMg}\left(\mathrm{CO}_{3}\right)_{2}\right]$, the Calcite $\left[\mathrm{CaCO}_{3}\right]$, the quartz $\left[\mathrm{SiO}_{2}\right]$ and gypsum $\left[\mathrm{CaSO}_{4}\right]$ (Fig. 3).

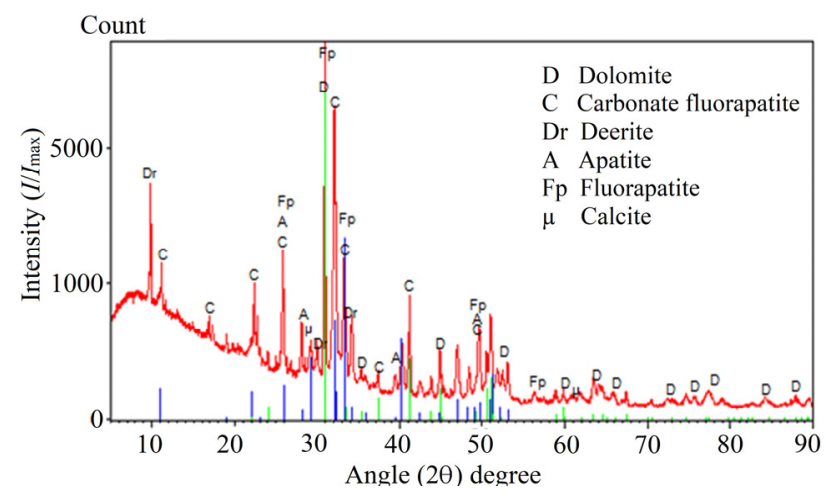

Figure 3. Diffraction pattern of phosphate tailing rejected from Djebel Onk complex 
The chemical analysis results of phosphate sludge are recapitulated in Table 1, from them we can noticed the presence of the following major elements: $\mathrm{P}_{2} \mathrm{O}_{5}$ as a useful substance with a content of $19.53 \%$, the $\mathrm{MgO}$ content is of $5.8 \%$ and $\mathrm{CaO}$ with an important content which is round $41.9 \%$.

Table 1. Chemical composition of Djebel Onk phosphate tailings

\begin{tabular}{lccccccccc}
\hline Component & $\mathrm{SiO}_{2}$ & $\mathrm{Al}_{2} \mathrm{O}_{3}$ & $\mathrm{Fe}_{2} \mathrm{O}_{3}$ & $\mathrm{CaO}$ & $\mathrm{MgO}$ & $\mathrm{SO}_{3}$ & $\mathrm{~K}_{2} \mathrm{O}$ & $\mathrm{Na}_{2} \mathrm{O}$ & $\mathrm{P}_{2} \mathrm{O}_{5}$ \\
\hline Content $\%$ & 11.70 & 1.93 & 0.61 & 41.9 & 3.85 & 2.42 & 0.29 & 0.00 & 19.53 \\
\hline
\end{tabular}

\subsection{Zeta potential measurements}

Zeta Potential measurements permit, first to study and to compare the fundamental properties of mineral surfaces, such as the electrical characteristics of particle charge, and then to exanimate the interactions between minerals and different reagents. The tests are conducted on the particles of pure calcite and apatite of the class size less than $38 \mu \mathrm{m}$. (Kawatra \& Carlson, 2013). Numerous adsorption studies have shown that the ion involved in the adsorption of the anionic reagent is $\mathrm{Ca}^{2+}$, which composes all calcite minerals (Zhu, Qin, Chen, \& Liu, 2016; Silva et al., 2018; McDannell, Issler, \& O’Sullivan, 2019; Owens et al., 2019).

All tests were performed at a standard $\mathrm{pH}$ equal 8 , where the surface charges of calcite and apatite were overall negative. Therefore, selective separation between apatite and other calcite minerals may be feasible at neutral $\mathrm{pH}$ by using anionic reagents. At these conditions, the separation is practicable because both collector adsorption mechanisms (chemical and physical) are effectuated on the mineral surface (Silva et al., 2018).

The results of different measurements are illustrated on Figures 4 and 5. In the case of alkyl hydroxamic acid (Fig. 4). it is very clear that the different values of zeta potential between calcite and dolomite are important at various reagent concentrations.

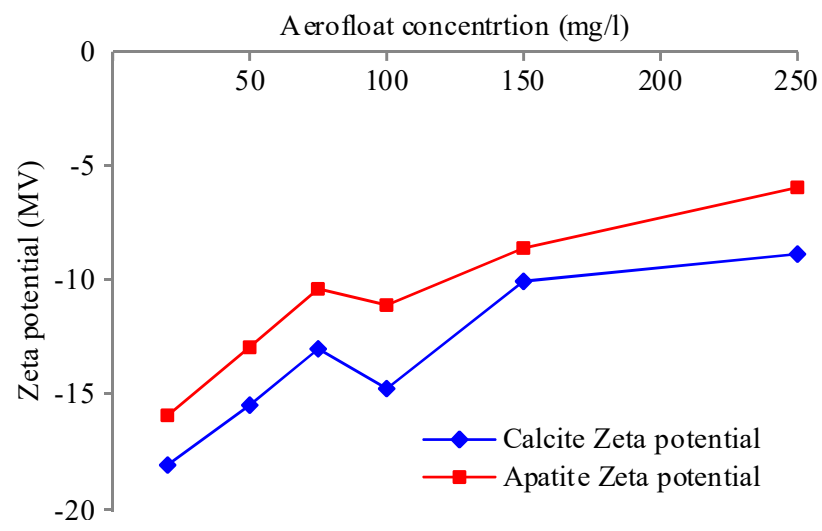

Figure 4. Zeta potential of apatite and calcite depending on AERO 6493 concentration

In the range of 20 to $75 \mathrm{mg} / \mathrm{l}$ of the concentration of AERO 6493, the zeta potential of both apatite and calcite gradually decreases, which explains a significant adsorption of the collector on the mineral surfaces.

However, in the case of Sodium oleate (Fig. 5), by the variation of the collector concentration from 0.03 to $0.30 \mathrm{mg} / \mathrm{l}$, the Zeta potential of calcite and dolomite decreases progressively, it means the minerals surfaces become more and more hydrophobic. These conditions consequently improve the floatability of minerals (Chettibi, Boutrid, Laraba, \& Abramov, 2015).

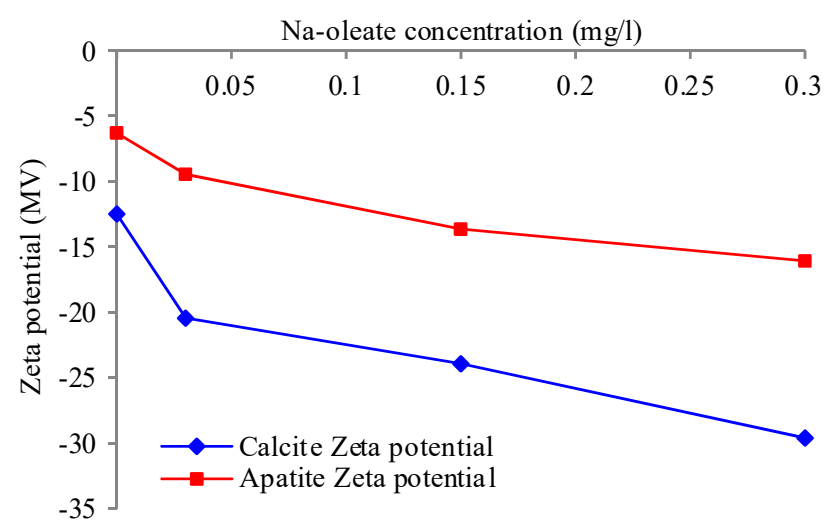

Figure 5. Zeta potential of apatite and calcite at various concentrate of Na-oleate concentration

\subsection{Flotation tests}

According to Figure 6, a very important floatability of apatite has been demonstrated with the use of alkyl hydroxamic acid as a collector. The increase to a maximum recovery at a concentration of $150 \mathrm{mg} / \mathrm{l}$ of the hydroxamic acid can be explained by the fact that the adsorption of the collector molecules on the mineral surface is very important.

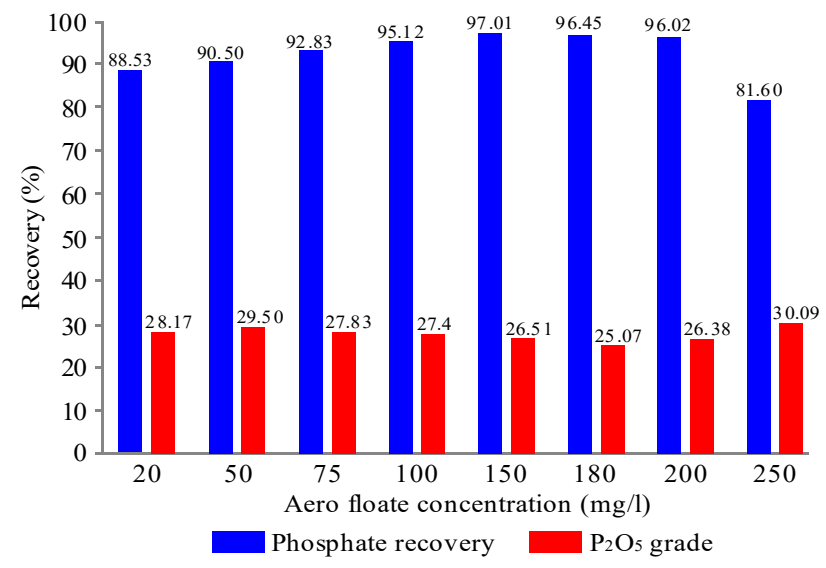

Figure 6. Flotation test of apatite depending on Aero 6493 concentration

By comparing the $\mathrm{P}_{2} \mathrm{O}_{5}$ contents determined in the different apatite recoveries, we found that the best recovery content value of $81.6 \%$ is produced at Aero 6493 concentration of $250 \mathrm{mg} / \mathrm{l}$ (Fig. 6). It means an optimal adsorption of the latter on the apatite mineral surface is realized (Filippova, Filippov, Duverger, \& Severov, 2014). There is also a significant difference in $\mathrm{P}_{2} \mathrm{O}_{5}$ levels when the concentrations of AERO 6493 were increased, the $\mathrm{P}_{2} \mathrm{O}_{5}$ content varied from $25.07 \%$ for a concentration of $180 \mathrm{mg} / \mathrm{l}$ and $30.09 \%$ at a concentration of $250 \mathrm{mg} / \mathrm{l}$ as a maximum value. The average content of $\mathrm{P}_{2} \mathrm{O}_{5}$ defined in the flotation tests with AERO 6493 is about $27.6 \%$. 
In the case of using sodium oleate, the obtained results of flotation are illustrated on Figure 7. The recovery values are quite low, almost for all concentrations except for $3.04 ; 15.20 ; 24.32 \mathrm{mg} / \mathrm{l}$ ones, in which they are very important and corresponded to $86.70 ; 83.51$ and $69.32 \%$ respectively. However, the content of $\mathrm{P}_{2} \mathrm{O}_{5}$ in the flotation concentrate is very high, the average value determined according to Figure 7 equals to $27.74 \%$ and this represents a phosphate concentrate of a good quality from a commercial point of view.

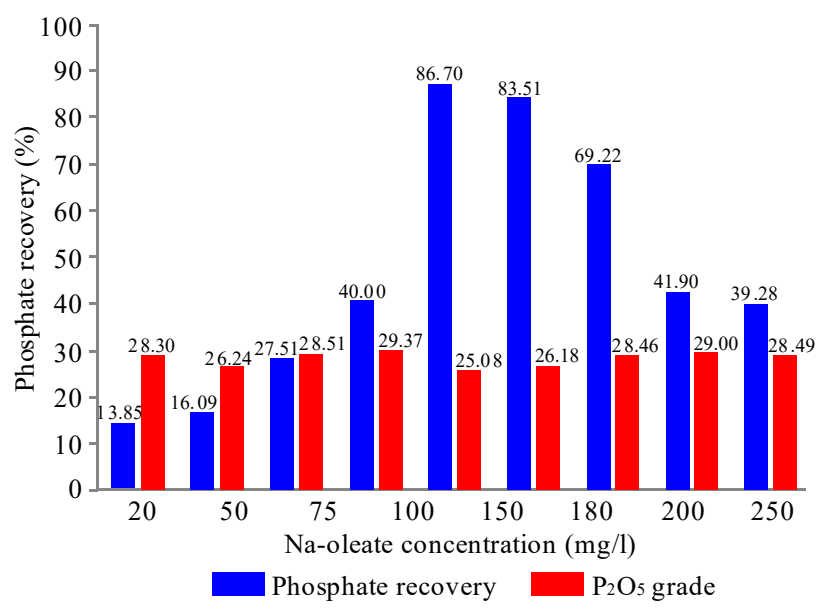

Figure 7. Flotation test of apatite depending on Na-oleate concentration

Comparative analysis of the results of flotation tests for apatite by alkyl hydroxamic acid (AERO 6493) and sodium oleate, at various concentrations, shows that the recovery is better with AERO 6493, especially at concentrations higher than $20 \mathrm{mg} / \mathrm{l}$, the average recovery obtained is about $92.26 \%$. However, in the case of sodium oleate, the flotation recovery still remains very low with an average value of $39.28 \%$. These results are confirmed by other studies reporting that alkyl hydroxamic acid (AERO 6493) is a good collector for the apatite flotation (Cao et al., 2015; Deng, Zhao, Zhong, Wang, \& Liu, 2016; Mâamri, Abbassi, \& Batis, 2016).

\section{CONCLUSIONS}

The results reported in this work, based on granular analysis, chemical analysis, zeta potential measurements and flotation tests, allow a detailed characterization of the phosphate tailings of Djebel Onk deposit, and they can be summarized in the following points:

1. The mineralogical composition is marked by the presence of the following mineralogical phases: Carbonate apatite $\left[\mathrm{Ca}_{10}\left(\mathrm{PO}_{4}\right)_{6}\right]$, Carbonate hydroxyapatite $\left[\mathrm{Ca}_{10}\left(\mathrm{PO}_{4}\right)_{3}\left(\mathrm{CO}_{3}\right)_{3}(\mathrm{OH})_{2}\right]$; Fluor-apatite [Ca5(PO4)3F]; Carbonate fluorapatite $\left[\mathrm{Ca}_{10}\left(\mathrm{PO}_{4}\right)_{5} \mathrm{CO}_{3} \mathrm{~F}_{1,5}(\mathrm{OH})_{0,5}\right]$; hydroxyapatite $[\mathrm{Ca} 5(\mathrm{PO} 4) 3(\mathrm{OH})]$ and hydrated phosphate, but the elements of gangue are represented essentially by: dolomite $\left[\mathrm{CaMg}\left(\mathrm{CO}_{3}\right)_{2}\right]$, silica in Calcite form [Ca$\left.\mathrm{CO}_{3}\right]$; quartz $\left[\mathrm{SiO}_{2}\right]$ and gypsum $\left[\mathrm{CaSO}_{4}\right]$.

2. Optimal Zeta potential value, necessary for a maximal apatite recovery is located $-15 \mathrm{mV},-25 \mathrm{mV}$ corresponded to the concentrations $100 \mathrm{mg} / 10,3 \mathrm{mg} / \mathrm{l}$ respectively.
3. The flotation of the phosphate tailings were carried out by the use of two reagents Sodium oleate and alkyl hydroxamic acid permitted to get significant results, particularly, at a concentration of $250 \mathrm{mg} / \mathrm{l}$ with a content of $30.9 \% \mathrm{P}_{2} \mathrm{O}_{5}$ and a recovery equals $81.6 \%$. Generally, in all flotation tests with AERO 6493, the obtained concentrates are acceptable as a commercial product.

The beneficiation of phosphate tailings rejected from Djebel Onk phosphate plant contributes strongly in the development of the national economy, in the protection of the environment and preserves both the nature and the human life.

\section{ACKNOWLEDGEMENTS}

We would like to thank our colleagues of Laboratory of Mineral Processing and Environment "LAVAMINE" Badji Mokhtar University Annaba, the laboratory of ENSMM Annaba for their assistance to complete the analysis tests and also, we are grateful for all the staff of the Mineral Processing Engineering Department of ITUIstanbul, Turkey.

\section{REFERENCES}

Bezzi, N. (2005). Gestion de la qualité et valorisation des minerais de Djebel Onk-Tébessa. Thèse Doctorat de l'Université Ferhat Abbas-Sétif.

Boujlel, H., Daldoul, G., Tlil, H., Souissi, R., Chebbi, N., Fattah, N., \& Souissi, F. (2018). The beneficiation processes of lowgrade sedimentary phosphates of Tozeur-Nefta deposit (Gafsa-Metlaoui Basin: South of Tunisia). Minerals, 9(1), 2. https://doi.org/10.3390/min9010002

Cao, Q., Cheng, J., Wen, S., Li, C., Bai, S., \& Liu, D. (2015). A mixed collector system for phosphate flotation. Minerals Engineering, (78), 114-121. https://doi.org/10.1016/j.mineng.2015.04.020

Chettibi, M. (2014). Sphalerite and its depression optimal conditions by zinc sulphate. International Journal of Current Research, 6(2), 5252-5257.

Chettibi, M., \& Abramov, A.A. (2016). Development of sphalerite activation regularity by copper sulphate. Journal of Mining Science, 52(5), 1003-1010. https://doi.org/10.1134/s1062739116041526

Chettibi, M., Boutrid, A., Laraba, A., \& Abramov, A.A. (2015). Optimization of physicochemical parameters of pyrite flotation. Journal of Mining Science, 51(6), 1262-1270. https://doi.org/10.1134/s1062739115060576

Deng, L., Zhao, G., Zhong, H., Wang, S., \& Liu, G. (2016). Investigation on the selectivity of $\mathrm{N}$-((hydroxyamino)alkyl) alkylamide surfactants for scheelite/calcite flotation separation. Journal of Industrial and Engineering Chemistry, (33), 131-141. https://doi.org/10.1016/j.jiec.2015.09.027

Filippova, I.V., Filippov, L.O., Duverger, A., \& Severov, V.V. (2014). Synergetic effect of a mixture of anionic and nonionic reagents: $\mathrm{Ca}$ mineral contrast separation by flotation at neutral pH. Minerals Engineering, (66-68), 135-144. https://doi.org/10.1016/j.mineng.2014.05.009

Gallala, W., Herchi, F., Ali, I.B., Abbassi, L., Gaied, M.E., \& Montacer, M. (2016). Beneficiation of phosphate solid coarse waste from Redayef (Gafsa Mining Basin) by grinding and flotation techniques. Procedia Engineering, (138), 85-94. https://doi.org/10.1016/j.proeng.2016.02.065

Habashi, F. (2017). Researches on phosphate rock fertilizer, uranium, rares earths, fluorine. Montréal, Canada: Métallurgie Extractive Québec. 
Horta, D.G., Monte, M.B.M., \& Leal-Filho, L.S. (2017). Effect of dissolution kinetics on flotation response of calcite with oleate. Brazilian Journal of Chemical Engineering, 34(4), 1035-1042. https://doi.org/10.1590/0104-6632.20170344s20150779

Ibrahim, S.S., El Kammar, A.M., \& Guda, A.M. (2015). Characterization and separation of pyrite from Abu Tartur black shale. International Journal of Mining Science and Technology, 25(4), 565-571. https://doi.org/10.1016/j.ijmst.2015.05.008

Kawatra, S.K., \& Carlson, J.T. (2013). Beneficiation of phosphate ore. Englewood, United States: Society for Mining, Metallurgy \& Exploration.

Mâamri, A.J., Abbassi, L., \& Batis, H.N. (2016). Characterization of the Oum El Khacheb phosphorites (South Tunisia) and enrichment of big rejections by grinding. International Journal of Mining Science and Technology, 26(5), 833-842. https://doi.org/10.1016/j.ijmst.2016.05.053

McDannell, K.T., Issler, D.R., \& O’Sullivan, P.B. (2019). Radiation-enhanced fission track annealing revisited and consequences for apatite thermochronometry. Geochimica et Cosmochimica Acta, (252), 213-239. https://doi.org/10.1016/j.gca.2019.03.006

Nettour, D. (2018). Caractérisation et élaboration d'un nouveau schéma de traitement des minerais de phosphate, cas de la mine de Djebel Onk, Tébessa. Thèse de doctorat de l'Université Badji Mokhtar Annaba.

Nettour, D., Chettibi, M., Bouhedja, A., \& Bulut, G. (2018). Determination of physicochemical parameters of Djebel
Onk phosphate flotation (Algeria). Naukovyi Visnyk Natsionalnoho Hirnychoho Universytetu, (4), 43-49. https://doi.org/10.29202/nvngu/2018-4/8

Owens, C.L., Nash, G.R., Hadler, K., Fitzpatrick, R.S., Anderson, C.G., \& Wall, F. (2019). Apatite enrichment by rare earth elements: A review of the effects of surface properties. Advances in Colloid and Interface Science, (265), 14-28. https://doi.org/10.1016/j.cis.2019.01.004

Rao, B.V., Velan, H.K., Jamal, S.I., \& Mahadevan, R. (2014). Grade-recovery prediction of an operating plant using flotation model and operating conditions. Procedia Engineering, (83), 148-158. https://doi.org/10.1016/j.proeng.2014.09.033

Silva, A.C., Cara, D.V.C., Silva, E.M.S., Leal, G.S., Machado, A.M., \& da Silva, L.M. (2018). Apatite flotation using saponified baker's yeast cells (Saccharomyces cerevisiae) as a bioreagent. Journal of Materials Research and Technology, 8(1), 752-758. https://doi.org/10.1016/j.jmrt.2018.05.018

Yassine, T. (2017). Valorisation des rejets miniers dans la fabrication de briques cuites: évaluations technique et environnementale. Thèse de doctorat de l'université CADI Ayyad Maroc 2017. https://doi.org/10.13140/RG.2.2.19573.78565

Zhu, H., Qin, W., Chen, C., \& Liu, R. (2016). Interactions between sodium oleate and polyoxyethylene ether and the application in the low-temperature flotation of scheelite at $283 \mathrm{~K}$. Journal of Surfactants and Detergents, 19(6), 1289-1295.

https://doi.org/10.1007/s11743-016-1864-1

\section{ЗБАГАЧЕННЯ ФОСФАТНОГО ШЛАМУ 3 ВІДХОДІВ НА ЗАВОДІ ДЖЕБЕЛЬ ОНК (АЛЖИР)}

\section{Д. Неттур, М. Четтібі, Г. Булут}

Мета. Вилучення максимально чистого $\mathrm{P}_{2} \mathrm{O}_{5} 3$ хвостів на фосфатному заводі Джебель Онк (Східний Алжир) 3 метою отримання з відходів високоякісного концентрату на основі флотаційних випробувань для забезпечення додаткового доходу, збереження здоров’я населення й запобігання забруднення навколишнього середовища важкими металами.

Методика. Для досягнення мети були використані наступні методи: гранулометричний і рентгеноструктурний аналіз для визначення складу хвостів та вибору відповідного реагенту для забезпечення якісної флотації. Флотаційні випробування проводилися із використанням олеату натрію в якості збирача та алкіл-гідроксамової кислоти (AERO 6493) в якості збирача й піноутворювача, системи для вимірювання зета-потенціалу фосфатних хвостів і визначення його оптимальних значень, які забезпечують найкраще поглинання з поверхні часток.

Результати. Гранулометричний аналіз дозволив виділити основний компонент, при якому фракція розміром менше 125 мкм склала $76.77 \%$; вагова частка другого компонента із розміром фракції $(-200+125)$ мкм становила близько $18 \%$; і третій компонент був представлений великими частками розміром більше 200 мкм, які зайняли всього 4.94\%. Однак, у разі використання AERO 6493 можливим є вилучення 97\% за умови щільності концентрату 150 мг/л і $26.51 \%$ вмісту $\mathrm{P}_{2} \mathrm{O}_{5}$. 3 іншого боку, флотаційні випробування із використанням олеату натрію показали низький рівень вилучення фосфату при високому вмісті $\mathrm{P}_{2} \mathrm{O}_{5}-$ до $30 \%$.

Наукова новизна. Вперше доведено (з 1965 року) ефективність вилучення фосфатів із дрібної фракції хвостів збагачення поряд з вилученням із них важких металів на заводі Джебель Онк. До цього хвости не підлягали переробці, а розміщувалися за межами комплексу.

Практична значимість. Використання алкіл-гідроксамової кислоти різної концентрації під час флотаційних випробувань дозволило досягти найбільшого вилучення фосфатів при мінімальних витратах на експлуатацію, транспорт, подрібнення й перемелювання. Це дозволить збільшити продуктивність комплексу Джебель Онк і зберегти стан навколишнього середовища.

Ключові слова: фосфатний комплекс Джебель Онк, хвости, збагачення, флотація, реагенти, алкілгідроксамова кислота

\section{ОБОГАЩЕНИЕ ФОСФАТНОГО ШЛАМА ИЗ ОТХОДОВ НА ЗАВОДЕ ДЖЕБЕЛЬ ОНК (АЛЖИР)}

\section{Д. Неттур, М. Четтиби, Г. Булут}

Цель. Извлечение максимально чистого $\mathrm{P}_{2} \mathrm{O}_{5}$ из хвостов на фосфатном заводе Джебель Онк (Восточный Алжир) с целью получения из отходов высококачественного концентрата на основе флотационных испытаний для обеспечения дополнительного дохода, сохранения здоровья населения и предотвращения загрязнения окружающей среды тяжелыми металлами. 
Методика. Для достижения цели были использованы следующие методы: гранулометрический и рентгеноструктурный анализ для определения состава хвостов и выбора подходящего реагента для обеспечения качественной флотации. Флотационные испытания проводились с использованием олеата натрия в качестве собирателя и алкил-гидроксамовой кислоты (AERO 6493) в качестве собирателя и пенообразователя, системы для измерения зета-потенциала фосфатных хвостов и определения его оптимальных значений, которые обеспечивают наилучшее поглощение с поверхности частиц.

Результаты. Гранулометрический анализ позволил выделить основной компонент, при котором фракция размером менее 125 мкм составила $76.77 \%$; весовая доля второго компонента с размером фракции $(-200+125)$ мкм была около $18 \%$; и третий компонент был представлен крупными частицами размером более 200 мкм, которые составили всего 4.94\%. Однако, в случае использования AERO 6493 возможно извлечение $97 \%$ при условии плотности концентрата 150 мг/л и $26.51 \%$ содержания $\mathrm{P}_{2} \mathrm{O}_{5}$. С другой стороны, флотационные испытания с использованием олеата натрия показали низкий уровень извлечения фосфата при высоком содержании $\mathrm{P}_{2} \mathrm{O}_{5}$ - до $30 \%$.

Научная новизна. Впервые доказана (с 1965 года) эффективность извлечения фосфатов из мелкой фракции хвостов обогащения наряду с удалением из них тяжелых металлов на заводе Джебель Онк. До этого хвосты не подвергались переработке, а размещались за пределами комплекса.

Практическая значимость. Использование алкил-гидроксамовой кислоты различной концентрации во время флотационных испытаний позволило достичь наибольшего извлечения фосфатов при минимальных затратах на эксплуатацию, транспорт, измельчение и перемалывание. Это позволит увеличить производительность комплекса Джебель Онк и сохранить состояние окружающей среді.

Ключевые слова: фосфатный комплекс Джебель Онк, хвосты, обогащение, флотация, реагенты, алкилгидроксамовая кислота

\section{ARTICLE INFO}

Received: 19 March 2019

Accepted: 25 October 2019

Available online: 5 November 2019

\section{ABOUT AUTHORS}

Djamel Nettour, Doctor of Philosophy, Associate Professor of the National School of Mines and Metallurgy (ENSMM); Laboratory of Mineral Processing and Environment "LAVAMINE", Earth Science Faculty, Badji Mokhtar University, Amar Laskri. ex-CEFOS Chaiba BP 233 RP, Annaba, Algeria. E-mail: djamel.nettour@ensmm-annaba.dz

Mohamed Chettibi, Doctor of Philosophy, Professor of the Laboratory of Mineral Processing and Environment "LAVAMINE”, Earth Science Faculty, Badji Mokhtar University, 23000, Annaba, Algeria. E-mail: chettibi2005@yahoo.fr

Gülay Bulut, Doctor of Philosophy, Professor of the Mineral Processing and Engineering Department, Mining Faculty, Istanbul Technical University, Maslak-34469, Istanbul, Turkey. E-mail: gbulut@itu.edu.tr

Aissa Benselhoub, Doctor of Philosophy, Senior Researcher at the Laboratory of Mining Resources Valorization and Environment, Badji Mokhtar University, 23000, Annaba, Algeria. E-mail: benselhoub@yahoo.fr 